\title{
SCANDINAVIAN CRIME FICTION
}

JAKOB STOUGAARD-NIELSEN 
For Federica, Lukas and Emma 


\section{[A] CONTENTS}

$\underline{\text { Acknowledgements }}$

Introduction

Chapter 1. Scandinavian Crime Fiction and the Welfare State

Chapter 2. Welfare Crime: Sjöwall and Wahlöö's Novel of a Crime

Chapter 3. The Hardboiled Social Worker: Gunnar Staalesen's Varg Veum

Chapter 4. Crime Fiction in an Age of Crisis: Henning Mankell's Faceless Killers and Stieg

Larsson's The Girl with the Dragon Tattoo

Chapter 5. Landscape and Memory in the Criminal Periphery

Chapter 6. Criminal Peripheries: Peter Høeg's Miss Smilla's Feeling for Snow and Kerstin

Ekman's Blackwater

Chapter 7. Investigating the Family in the Welfare State

Conclusion

Bibliography

Index 


\section{[A] ACKNOWLEDGEMENTS}

This book grew out of a series of meetings and conversations in London's Nordic Noir Book Club. The Book Club was conceived in 2010 as a way for scholars and students in the Department of Scandinavian Studies, University College London, to engage with fans and readers of Scandinavian crime fiction in an exploration of what the success of 'Nordic Noir' could tell us about how Nordic cultures and societies are presented and understood in the UK through the popular forms of translated and subtitled crime fiction. I am particularly grateful to the many members of the Nordic Noir Book Club, who have generously shared their insights and enthusiasm for crime fiction and the Nordic countries. I would like to extend my gratitude to colleagues and students for their collaboration and dedication to advancing our understanding and appreciation of contemporary Nordic languages, cultures and societies through the Book Club. Special thanks to Karin Charles, Claire Thomson, Mary Hilson, Elettra Carbone, Helga Lúthersdóttir, Jesper Hansen, John Mitchinson, Annika Lindskog, Agnes Broome, Nicky Smalley, Pei-Sze Chow and Henriette Steiner.

It has been a special treat of the Book Club to meet and listen to crime writers from the

Nordic countries including Haakan Nesser, Yrsa Sigurðardóttir, Gunnar Staalesen, Thomas Enger, Jussi Adler-Olsen, Sissel-Jo Gazan, Lene Kaaberbøl and Agnete Friis; the translators 
Victoria Cribb and Mark Mussari; the producer Francis Hopkinson; the director Annette K. Olesen; and the critics Hans Skei, Gunhild Agger and Bo Tao Michaëlis. A special thanks to Barry Forshaw, who has been an invaluable presence in the Book Club, a force in the promotion and appreciation of Nordic crime fiction in the UK and an insightful and enthusiastic 'partner in Nordic crime' over the recent years. I am also grateful for the support provided by the Nordic Embassies in London, in particular Lone Britt Christensen and Kirsten Syppli Hansen at the Embassy of Denmark. Throughout my work on this book, I have had the opportunity to present my ideas and share my interest in Scandinavian crime fiction with a wide audience, and I am grateful to Jonathan Sadler at Arrow Films for inviting me to speak at the Nordicana festival in London and to Vibeke Johansen for invitations to speak at the Horsens Crime Fair in Denmark.

I have benefitted immensely from presenting and discussing my work-in-progress in research networks with excellent and most generous colleagues. Particular thanks to Peter Simonsen and Anne-Marie Mai at University of Southern Denmark, whose innovative research into Danish literature and the welfare state has influenced the central perspective presented in this book. My work in the area of literature and society has benefitted greatly from continuing conversations and collaborations with Svend Erik Larsen, Leverhulme Visiting Professor at UCL Scandinavian Studies in 2013, and David Napier, Director of the UCL Science, Medicine and Society Network.

Earlier versions of sections in chapters one and seven have previously appeared in a Post45 Contemporaries special series ('Nordic Noir') edited by Bruce Robbins and in a special issue of Aktuel Forskning ('Velværelsen: Ny humanistisk velfærdsforskning') edited by Peter Simonsen. I am particularly indebted to Bruce Robbins's advice for my work on Anne Holt and 
post-Utøya crime fiction.

This book might never have materialized if it wasn't for the series editor Katy Shaw's initial proposal and continuous encouragements. I am deeply grateful to her for this opportunity and for her editorial acumen, which has greatly improved the final book. My gratitude also to my publisher and editors at Bloomsbury, whose professionalism and patience nurtured the project at every stage. Special thanks to David Avital and Mark Richardson.

Final thanks to my parents, Benny and Eva, who brought me up a Danish welfare citizen and an all-consuming reader; and to Federica, Lukas and Emma who make it all possible and worthwhile. This book is for you. 


\section{[A]Introduction}

\section{[B] Stockholm Syndrome}

On 23 August 1973, a masked Janne Olsson entered Kreditbanken on Stockholm's

Norrmalmstorget (Norrmalms Square). He drew a submachinegun from under his coat, fired at the ceiling and shouted in English to disguise his identity: 'Get down to the floor! The party starts.' What could have been the beginning of just another bank robbery soon evolved into a nail-biting six-day hostage crisis. Olsson demanded three million kronor, a fast getaway car, safe conduct out of the country accompanied by the hostages and, curiously, the release of his friend, the notorious criminal Clark Olofsson, who was serving time in Norrköping prison for armed robbery and as an accessory in the murder of a policeman in 1966. The police agreed to the requests. Notes were counted, a blue Ford Mustang was parked on the square, and Olofsson was escorted to the bank where he joined Olsson and the four hostages. However, the Minister of Justice Lennart Geijer, in agreement with Prime Minister Olof Palme, refused to let Olsson leave the bank with the hostages.

The following stand-off between the hostage taker and the police was followed intensely by the national and international media and broadcast live on television. Phone interviews with the hostages from the bank were broadcast on public radio. One of the hostages even called 
Prime Minister Palme and pleaded with him to let her and the other hostages leave the bank with Olsson - she was, she explained, more afraid of the police attacking and killing them than she was of her captor, who 'had been very nice' (Graham et al 1994: 5; Cronqvist et al 2008: 46). In the end the police decided to force Olsson to give in by pumping tear gas through a hole drilled in the ceiling of the vault, and the situation was resolved with no physical harm to the hostages and their captors.

What made this attempted bank robbery and hostage taking the most infamous in Swedish history was not, however, the ultimate success of an otherwise ill-prepared police force. The reason why we still recall this incident today is mainly due to the fact that it became synonymous with the psychological syndrome to which the Swedish capital lent its name: the Stockholm Syndrome. Over the six days, it became oddly apparent to the police and the general public that the hostages seemed to develop deep sympathies with their taker.

Viewed from the vantage point of a twenty-first-century media culture, saturated with reality-TV game shows and a 24-hour news cycle thriving on sensationalism and the breakdown of traditional notions of what constitutes 'public interest', the mass-mediated drama in and around Kreditbanken appeared well ahead of its time. Per Svensson has called the Norrmalms Square drama the first live-transmitted docudrama in Sweden (Svensson 2003). The bank robbery could have been just another abstract figure in the crime statistics of the well-managed Swedish welfare state or a classic narrative about incurable career criminals, terrified hostages and a successful police force that in the end reinstates trust in the justice system and a belief in the persistence of the 'good state'. However, the 'actors' did not conform to their expected roles. The hostages did not seek to escape when given the opportunity, Olofsson's role as part notorious criminal and part go-between between Olsson and the police was confusing and 
Olsson, as described by the hostages, did not conform to the image of a ruthless criminal. Instead, the drama that played out on the nation's TV screens conformed to already ongoing revisions of crime and its psychological as well as social conditions in the increasingly more popular home-grown crime fiction that gradually took over the bestseller lists in Sweden as well as in Denmark and Norway in the same period.

This book is an investigation into the murky contact zone between the dramatic and still on-going changes in perceptions of Scandinavian social realities, attached to the 'rise and fall' or the 'crisis' of the welfare state since the early 1970s, and the equally dramatic history of the national, regional and international obsession with a more or less distinct, localized Scandinavian take on the most globalized of popular genres: crime fiction. I consider the Norrmalms Square drama a suggestive way into this story for several reasons, which I hope will become apparent as this book progresses: it dramatized a growing distrust in the inevitable 'goodness' of the Scandinavian welfare state, it displayed ambiguities in traditional perceptions of good and evil and, perhaps more than any other 'true crime' story, it initiated an age where crime and crime investigation became the dominant mass-spectacle across media as the new 'normal' genre. The Norrmalms Square drama unfolded at the beginning of an era which would witness the unprecedented commercial success of Scandinavian crime fiction on the page and on the screen across the Nordic countries, culminating in nothing less than a global literary and media phenomenon in the first decade of the twenty-first century (Berglund 2012; Handesten 2014: 433; Nestingen and Arvas 2011:1).

\section{[B] Crime fiction for comfort junkies}

Leonard Cassuto has said of genre fiction that it should be read as a 'cultural symptom, not a 
cultural cure' (Cassuto 2009: 16). Perhaps some genres and some stories more than others 'scratch a collective itch that appeared at a specific time' and as all 'complicated cultural symptoms, that itch has a lot of causes' (261).

It has been suggested that 1973 was the year in which the, in many ways, still content, affluent and progressive ideal of the Swedish welfare state started to crack - a year that also witnessed the exposure of the IB-affair, the possible high-level political involvement in the Swedish intelligence agency's illegal monitoring of the political Left: 'It was a time initiating a change of roles between inside and outside, centre and periphery, good and evil, honest and dishonest, criminal and police, victim and culprit' (Cronqvist et al: 38). In his book about the Norrmalms Square drama, Per Svensson suggests that it initiated a new epoch in Sweden; it symbolized 'the shattered illusion of the Swedish comfort junkies about the ability of the welfare state to expunge evil from society' (Stenius 2004; Svensson 2003).

Proceeding from this diagnosis of a shattered self-perpetuated collective image of the harmonious welfare state, where perceived notions of what constitutes the 'good society' were turned on their head, Slavoj Žižek’s dialectical analysis of violence may throw further light on the significance of this wider social Stockholm syndrome, which in various forms would come to inform contemporary Scandinavian crime fiction. Olsson's ‘subjective violence' ('violence performed by a clearly identifiable agent') against the hostages, police and the bank can be seen as symptomatic of a deeper 'systemic violence' made invisible, so to speak, by illusions created by the welfare state itself. 'Systemic violence', as Žižek notes, pertains to the 'catastrophic consequences of the smooth functioning of our economic and political systems' - an illusion of comfort underwritten by the very forces that the 'smooth' system actively seeks to dispel (Žižek 2008: 1-2). 
The potential of crime fiction as a privileged genre through which to detect the symptoms of the 'shattered illusion of comfort' in order to reveal the 'systemic violence' inherent to the Social Democratic welfare state was central to the final instalments of Sjöwall and Wahlöö's trendsetting crime serial Novel of a Crime (1965-75). From a clear ideological standpoint on the radical New Left, they went behind the facades of an idyllic Stockholm to depict a dystopian and totalitarian Swedish welfare state where innocent individuals were pushed into criminal activities by a corrupt, alienating and consumerist welfare state that had sold out to capitalist interests.

Scandinavian crime writers have since then continued to use a great variety of crime fiction's sub-genres to 'scratch the collective itch'. As Scandinavian crime fiction became increasingly preoccupied with the social conditions of crime, readers were asked to sympathize with vigilante law breakers and to question the morals of the welfare state and its promise of social justice. In Swedish police procedurals from Sjöwall and Wahlöö to Henning Mankell's Wallander series (1991-2009) and the global phenomenon of Stieg Larsson's genre-hybrid Millennium trilogy (2005-2007), eccentric and victimized women are abandoned, if not outright assaulted, by the justice system and the welfare state. Some like Larsson's Lisbeth Salander became unlikely Scandinavian heroines bestowed with the detectives' and readers' sympathies even if, or perhaps because, she was ready to take the law into her own hands when abandoned by the state and its representatives.

In psychological crime thrillers by the Dane Anders Bodelsen (1968-), in Gunnar Staalesen's Norwegian hardboiled Varg Veum series (1977-) and in later procedurals by the Swede Arne Dahl, a persistent genre trait in Scandinavian crime writing is taking shape as detectives', victims' and criminals' familial conflicts and alienation in an inauthentic, urban consumer society is presented as intricately connected to the welfare state's rational and amnesic 
obsession with progress and social engineering. Crimes are here viewed as symptoms of deeper or wider mostly invisible social processes, in front of which detectives such as Mankell's Kurt Wallander are left utterly helpless and desperately anxious. The crimes recorded in Scandinavian crime fiction, this book will propose, are symptoms of an age of uncertainty where the comforts of the welfare state have ceased to provide the ointment that may relieve the collective itch.

Svensson's diagnosis of the 'collective itch' that began to irritate the social body of the 'comfort junkies' in the early 1970s is illustrative of the socio-critical preoccupations of much of the crime writing that began to appear in the same period across Scandinavia. It is also symptomatic of a notable shift in the foreign gaze on Sweden, which in turn became internalized in the local gaze of home-grown crime writing. In 1936, the American journalist Marquis Childs published the international bestseller Sweden: The Middle Way. Written in the time of the Great Depression, Childs viewed the Swedish Social Democratic compromise between liberal capitalism and state communism as a pragmatic model that could guarantee full employment, social security and equality without jeopardising economic development and democratic institutions. Even to this day, the utopian image persists abroad in various shapes and forms when, for instance, the popular Democratic US Presidential candidate Bernie Sanders in 2015 talked about his version of democratic socialism as inspired by the successes of the Scandinavian welfare states, or when the news media report on international surveys such as the World Happiness Report or the OECD Better Life Index that rank the Scandinavian countries amongst the happiest in the world.

However, in the 1970s, this utopian view on Sweden and the Social Democratic welfare state changed radically with the British journalist Roland Huntford's controversial book The New Totalitarians (1971). To Huntford, Swedes, dominated by the Social Democratic party for 
forty years, had come closer to living in Aldous Huxley's dystopian Brave New World than the Soviets - a totalitarian state where individual freedoms had been sacrificed willingly for state guaranteed comforts and material wealth. Even Sweden's otherwise much admired sexual liberalism became an expression of totalitarian state control in Huntford's opinion. High suicide rates and heavy taxation were other less than perfect trends he sought to highlight. Huntford's acerbic portrayal of Sweden in the early 1970s has certainly dated but has also found a more contemporary voice in the British journalist Michael Booth's tongue-in-cheek travelogue The Almost Nearly Perfect People: The Truth About the Nordic Miracle (2014) in its portrayal of conformist Swedes, jingoistic Danes on anti-depressants, lethargic Norwegians drunk on oil wealth, and gun-toting, binge-drinking Finns. However, it is not only British journalists who have looked behind the idyllic facade of the Swedish and Scandinavian welfare states. In Jan Troell's 1988 documentary Sagolandet (The Land of Dreams), for instance, a decaying alienating welfare state is portrayed with contrasting images of the modern consumer society and its destruction of nature, creativity and an idyllic childhood.

As Michael Tapper has pointed out in his work on the Swedish police procedural, it is curious how similar in perspective Huntford's liberal-conservative critique of the Swedish welfare state was to the contemporary dystopian sentiments held by many on the political and ideological New Left in Sweden - sentiments which found a popular form in the rise of the socio-critical Swedish police novel and, according to Tapper, may account for the wide appeal of Sjöwall and Wahlöö and later Mankell's novels (Tapper 2014: 87, 163). However, as I shall argue throughout this book, while Swedish and Scandinavian crime novels are sensitive to the systemic violence of the welfare state and preoccupied with showing the dark sides of the once 'idyllic' welfare states, novels from Sjöwall and Wahlöö's most dystopian portrayals of a 
criminal Swedish welfare state to Stieg Larsson's indictment against a violent, patriarchal society more than three decades later, from Gunnar Staalesen's portrayal of a morally corrupt, petroleum infused Norway to Anne Holt's investigation into a violent and broken nation-family in a postUtøya Oslo and from Anders Bodelsen's hyper-realistic depiction of a claustrophobic Danish, consumerist welfare society to Peter Høeg's critique of the systemic violence of Danish colonialism in Greenland, Scandinavian crime fiction is centrally preoccupied with how to restore the health of the social body in an age where the state and its representatives have lost their former self-evident moral authority.

\section{[B] A socio-critical genre}

With the central place of Sjöwall and Wahlöö's Novel of a Crime in modern Scandinavian crime fiction it is no surprise that subsequent crime writers and critics alike have used and explored the crime genre for its socio-critical reflections of life in the welfare state. Indeed, over the past decades crime fiction has been re-evaluated and invigorated as particular modes of writing wellsuited for capturing societies undergoing dramatic change, for representing and responding directly to an age of social conflicts, risks and inequalities.

The present book participates in this broad international discussion of crime fiction as a genre made for the crises, conflicts and indeterminacies belonging to the last decades of the twentieth and the first decades of the twenty-first century. This is the age of intensified globalization, an age of perpetual transience marked by the restlessness of a rampant global consumer society, the uprooting of identities, communities and nation states, a period characterized by Zygmunt Bauman as our 'liquid modernity' (Bauman 2012). Crime fiction is modern genre writing with a dense undergrowth of sub-genres and local expressions, borne out 
of the nineteenth century's obscure urban environments and labyrinthine modern state bureaucracy, which today has become a dominant literary form ready-made for a thoroughly globalized, mediated and fluid age.

This book is certainly not the first to explore the ways in which Scandinavian crime fiction reflects and responds to the late-modern welfare state and the changing social reality of the Scandinavian countries from the optimism of its 'solid' golden age through decades of uncertainties, angst and fluidity. Sara Kärrholm's study of the post-War 'golden age' of Swedish crime fiction is particularly interesting as it finds in the puzzle-crime novels by authors such as Stieg Trenter and Maria Lang contemporary moral sagas about good conquering evil, where the idyllic welfare state, as the country-houses of their British predecessors, is under a constant threat from outside forces (Kärrholm 2005). The crime novels of this period shore up values and communal responsibilities against the threats of an uncertain and encroaching Cold-War world. While the cultural work of the post-War whodunits, in Kärrholm's view, upheld and helped construct the idyll of the welfare state's modern familial and national collectives, Daniel Brodén's study of Swedish crime films from the Second World War and post-War years relates a complementary narrative where these early filmic experiments with the genre show an alternative interest in 'the shadows of the people's home' (Folkhemmets skuggbilder), the dark side of the welfare state (Brodén 2008). Swedish noir films, as the later police procedurals, according to Brodén, begin to shed a critical light on the uncanny or 'un-homely' ('hemsk') every-day life in the rapidly industrialising Swedish welfare state, or seemingly idyllic 'people's home' (12). In different ways, Kärrholm and Brodén employ crime fiction as cultural historical sources for exploring the increasingly more pressing uncomfortable ambivalences that disturb the idea of the idyllic Swedish welfare state - a society either constantly under siege or 
threatened by its own accelerated modernisation. The present study brings these ambivalences related to the welfare state and their negotiation in crime fiction into the late-modern period and broadens the view to include parallel developments in the three Scandinavian countries, Denmark, Norway and Sweden.

As the golden age of the welfare state faded, a new golden age of Scandinavian crime fiction ensued, and critics have over the most recent decade begun to explore and question why crime fiction, which of course does have a long and popular history also in the Scandinavian countries, has become so ubiquitous in the first decades of the twenty-first century. The obvious question to ask is how it can be that these seemingly peaceful, affluent, healthy and happy welfare states in Scandinavia, nations that are constantly being lauded for leading the world in European and global surveys, whose image abroad is mostly of safe if not rather boring orderly societies, are punching well above their weight in terms of the production and export of violent and often dystopian crime novels and TV series? In Ian Macdougall's review of Stieg Larsson's Millennium trilogy, 'The man who blew up the welfare state,' 'the country's well-polished façade' and 'welfare-state comforts', which is, he claims, what American readers would expect to find in depictions of Sweden, 'belies a broken apparatus of government' run by ubiquitous crooks. In Larsson's crime novels 'the state itself is the greatest villain,' and, Macdougall suggests, the novels' 'reliance on hard facts' (for example the statistics of violence against women, which Larsson reproduced as epigraphs) 'suggest that the crime novel we're reading is not a work of pure imagination' (Macdougall 2010). Barry Forshaw is another critic who has found that 'to some degree, the picture of Scandinavian society conveyed through its crime literature is an accurate one, though inevitably tendentious' (Forshaw 2012: 11).

Scandinavian crime writing since the 1970s has insisted on painting rather grim pictures 
of societies in which the welfare state has failed to protect the most vulnerable, where the welfare system is over-burdened and unable to care and where, even after half a century of social engineering, crime appears as present and wide-spread as ever. This apparent paradox does seem to be suggesting that all is not well in Scandinavia, assuming that the crime narratives provide a realistic view into the dark side of these Nordic utopias. While crime fiction does employ realistic descriptions of everyday lives, urban and natural locations in Scandinavia, and while crime writers, who in many cases are trained journalists (as, for instance, Per Wahlöö, Anders Bodelsen, Jan Guillou, Stieg Larsson, Liza Marklund, Sara Blædel and Mari Jungstedt) may present statistics or provide, as many of them do, postscripts in which they thank their wellplaced sources and informers for their help in the authors' research for the novels, crime fiction does not, of course, represent Scandinavian societies realistically, least of all when it comes to their inflated levels of crime - if it did, the small town of Ystad, the setting of Mankell's Wallander novels, would have seen more murders than the rest of Scandinavia combined. Why is it, then, that such dark, dystopian and excessively violent narratives have taken root in Scandinavia and been such a success abroad in the twenty-first century? Mary Evans posed the same question in a slightly different way in her book The Imagination of Evil: Detective Fiction and the Modern World (2009): 'So, why, we might ask, since most of us live generally safe, relatively prosperous and "crime free" lives, are we so fascinated by the pathology of crime, by the process of identification of the murderer or the unmasking of the criminal? (15) Part of her answer is that 'just as we might, arguably, have reached a point at which the social world becomes both relatively safe and relatively reliable, we have also imposed upon ourselves a myriad of new anxieties, in particular, the question of how to live up to the expectations of an (apparently) highly qualified world' (16). This is the world of the post- 
welfare state, the neoliberal competitive state, which, according to the Danish economist Ove K. Pedersen, has roots in the crises of the early 1970s, eventually replacing the Social Democratic welfare state in the 1990s (Pedersen 2011). The present book proceeds from Evans's suggestion that the ubiquity of crime fiction in Scandinavia, apart from being part of a wider global cultural phenomenon, uses generic crime narratives, the spectacle of the dead body and cordoned-off crime scenes in idyllic Scandinavian landscapes teeming with puzzled investigators, as proxies for investigations into wider and more complex 'new anxieties' produced by an increasingly competitive world marked by 'fluid' individualism, the denigration of the social state and the erosion of social trust between individuals, communities and institutions. Also in this sense, Scandinavian crime fiction can be seen to voice a social critique or perform cultural work relevant to particular national or regional conditions, using a global genre that has proven particularly well suited for exploring the symptoms, the itch, the anxieties arising from the less visible societal changes and systemic violence. According to Evans, 'of all fiction in the past 200 years, it is detective and crime fiction that has most vividly and often persuasively engaged with social reality' and 'reading fiction about crime is the most vivid account that we have of western societies' various fears and preoccupations' $(2,7)$.

\section{[B] A nostalgic genre}

Several of the crime novels discussed in this book investigate how individual desires and social responsibilities may be adjusted through collaboration and trust in order to produce and, at times in a sentimental or nostalgic mode, to reintroduce social justice, communal belonging, even comfort, in an age of wide-spread anxieties, where the Scandinavian countries have come to be seen as less the exceptional states they appeared to be in a polarized Cold-War world and more 
like everywhere else in a world of rapid globalization.

For this reason, while I agree with the widely shared perception that Scandinavian crime fiction, as crime fiction from many other regions of the world, should be viewed as a genre preoccupied with changing social realities and conflicts between more or less corrupted states and victimized individuals, I believe that the local as well as the international success of Scandinavian crime narratives on the page and on the screen is centrally tied to their at times nostalgic, sentimental and melodramatic insistence on values associated with fundamental, perhaps long forgotten, aspirations of the Scandinavian welfare societies. Such common values may have been expressed most programmatically in the Swedish Social Democrat Per Albin Hanson's famous 'people's-home' speech in 1928. His vision for a future welfare society based on social citizenship was modelled on the synecdoche of the 'good home' with its foundation in equality and mutual understanding: a home which would not be divided by social classes, but based on consideration, cooperation and helpfulness.

Scandinavian crime fiction, in my view, is as diverse as its various locations, languages, cultural and historical contexts may suggest, but also united in worrying about and nostalgically longing for the 'good home' and the comforts of a just, egalitarian welfare society in a turbulent and increasingly globalized world. It is a genre preoccupied with individuals and families, police officers, private investigators, forensic psychologists, journalists, victims of crime and criminals, who in various ways and by different means struggle to keep their homes together through cooperation, the cultivation of empathy, and by reclaiming individual freedoms through the cultivation of social trust.

Therefore, this book's exploration of what I call the Scandinavian welfare-crime novel does not merely find in the last four decades of Scandinavian crime writing a dystopian portrayal 
of the welfare state, but a widely shared nostalgic longing for an imagined past of social and cultural justice and belonging, a longing for better times, which in some cases turns out to be a 'paradise lost' and in some a partial realization of, or hope for, a better future. In this, my wider perspective on present discourses about the state of Scandinavian welfare, as exemplified in the dominant genres belonging to crime fiction, concurs with Jenny Andersson's study of a prevailing 'people's-home nostalgia' ( $\underline{\text { folkhemsnostalgin })}$ in Sweden, where the promises of a better society lie not, as in the golden age of the welfare state in the 1950s and 60s, in the near future, but in the missed opportunities of the past (Andersson 2009b). As in Svetlana Boym's study of nostalgia in post-1989 Eastern Europe, I do not consider nostalgic sentiments, as they are expressed in Scandinavian crime fiction, necessarily a bad thing (Boym 2001). Nostalgia can of course lead to anxieties about an unknown future, to xenophobia and ring-fencing of perceived ethnic values, to isolationism, but it can also help us face an uncertain future with shared values that may have suffered under the transformative pressures of modernisation, neoliberalism and globalization. In this sense, I propose to view Scandinavian crime fiction as a genre made for the twenty-first century, a nostalgic age as well as an age of social and financial crises, a late-modern, post-national age of wide-spread anxieties about formerly perceived stable identities, families, communities and welfare states, which have become, to many, dissipated, unrecognizable and uncanny 'homes' in the new millennium.

Crime fiction has at least since its nineteenth-century origins functioned as a seismograph for emerging conflicts and anxieties between individuals, the social order and the state, the state's (in)ability to police and discipline the alienating physical and social spaces of the growing cities or the breakdown of social structures in the national peripheries where mysterious and violent 
crimes became symptomatic for the uprooting and alienating effects of rapid modernisation (Symons 1974: 16; Mandel 1984: 29-30, 135; Scaggs 2005: 98-9). The social form of crime fiction is dependent upon and reflects local and national circumstances at particular moments in time where individuals' sense of belonging and identity 'thicken' around specific social insecurities and anxieties. A central argument and leitmotiv of this book is that the rise of Scandinavian crime fiction from the late 1960s to the first decades of the twenty-first century is intimately tied to the local disruptions associated with the late-modern or post-welfare society, which Shane McCorristine, with reference to the crime novels of Henning Mankell, has described as 'a sense of critical transition, a community that is envious of the past and uncertain about the future' (McCorristine 2011: 81). Such nostalgic sentiments inherent to the post-welfare state saturate post-1968 Scandinavian crime fiction; partly, I shall argue, because writers have been centrally concerned with giving a narrative shape to the shared experiences of unsettling social transformations.

Here, this book is indebted to Andrew Nestingen's seminal study Crime and Fantasy in Scandinavia (2008), wherein he demonstrates how popular and transnational genres have recently played a central role in 'reshaping Scandinavian national cultures' (257). Particularly the Scandinavian penchant for the police procedural, Nestingen suggests, must be seen in the light of its generic form ready-made (due to its focus on the collective of a police team representing the state) for exploring 'the social dynamics and ethical crisis of the Scandinavian nations' (217). Complementing the collective realism of the police novel, the increasingly more melodramatic mode of the crime novel in Scandinavia, Nestingen argues, is similarly well suited for 'contesting the morality of the welfare state's transformation under neoliberalism' (Nestingen 2011:172). The present study adds to this view of the social function of genre fiction, apart from 
its more holistic sample from the recent tradition of Scandinavian crime fiction, a discussion of a variety of nostalgic modes through which novels from the late 1960s to the 2000s construct a persistent view of not only what has gone wrong in the welfare state, what has been lost over the past four decades, but also what a 'good' state of the present and future might be.

This argument not only confirms the persistent realist and socio-critical ambitions of Scandinavian crime fiction, a central generic 'Nordic' trait noticed by most readers, reviewers and critics, but also points to a much wider historical and generic trait of crime fiction across sub-genres and cultural origins: In Ernest Mandel's Marxist-inspired critique of the classical detective story of the inter-war years, its inherent nostalgia is viewed as fulfilling the subjective needs of the 'upset, bored and anxious individual member of the middle class', and, more recently, Erik Dussere has argued that the gritty realism or 'authenticity effects' employed in the American noir tradition can be viewed as attempts to recapture, at times nostalgically, a lost 'elsewhere' in an American post-War era marked by the artificiality of an omnipresent consumer culture (Mandel: 29; Dussere 2014: 8-9). Scandinavian detectives, faced with an inscrutable, complex and violent world, knee-deep in personal and familial conflicts, wonder what has happened to the welfare state's promise of a better, more just, equal and trusting society - and they do so in their various Scandinavian languages and accents, yet in a (nostalgic) mode that conforms to the expected generic 'language' of crime fiction.

\section{[B] A global genre}

Scandinavian crime fiction is, on the one hand, thoroughly located within specific national concerns about the fate of the 'Nordic' universal welfare state under the increasingly globalized pressures of consumerism, transnational crime, neoliberalism, Europeanization and migration. 
On the other, however, these local, generic and societal concerns are perhaps also what have made these fictions travel beyond their local origins. Societal concerns about the erosion of communities, families, individual freedoms and welfare institutions are widely shared across the world having spawned international movements and national political upheavals in the wake of the global financial crisis in the first decade of the twenty-first century. Stieg Larsson's Män som hatar kvinnor (2005, The Girl with the Dragon Tattoo, 2008), 'the all-flattening juggernaut' of Scandinavian crime fiction, according to Barry Forshaw and, in Kerstin Bergman's assessment, the novel that turned Swedish crime fiction into a 'worldwide phenomenon,' is a good example of the global resonance of crime fiction's local responsiveness (Forshaw: 5; Bergman 2014: 11). As I argue in chapter four, an often overlooked point in this novel, behind its more dramatic theme of violence against women and terrifying Nazi-serial killers, is the social backdrop of financial crisis and loss of interpersonal trust, referring to the crisis in Sweden in the early 1990s. While most global readers probably know very little about Sweden and the wider socio-political consequences of this event, the novel might have resonated so widely as translations began to spread simultaneously with the unravelling of the global financial crisis of 2008; it is, after all, essentially a contemporary cautionary tale of financial corruption, its social consequences and an impotent welfare state.

In the twenty-first century, Scandinavian crime fiction, or 'Nordic Noir' as it has become labelled in the UK, became a local as well as a near-global obsession described as forming a recognizable international brand, which has spread like a wave from the Scandinavian epicentres to the mainstream European markets and beyond: Several crime series have been translated into more than thirty languages and authors such as the Swedes Henning Mankell, Stieg Larsson and Liza Marklund, the Norwegian Jo Nesbø and the Dane Jussi Adler-Olsen are selling millions of 
copies of their crime novels outside of Scandinavia (Nestingen and Arvas 2011; Forshaw 2012).

The wave of Scandinavian crime fiction, which initiated in the 1990s and intensified in the first decades of the twenty-first century, conforms to Franco Moretti's theory about the transnational spread of novelistic genres, emanating from the literary and cultural centres and influencing the peripheries through translations, adaptations and mimicry, eventually resulting in original local variants that add to and innovate the global form of the genre itself (Moretti 2000).The phenomenon of Scandinavian crime fiction demonstrates that crime fiction is a particularly mobile and adaptable genre, able to spread and take root throughout the world of literature. It may be argued that the popularity of Scandinavian crime fiction has played a central role over the recent decades in opening up the doors for crime writers around the world to the global and much coveted yet notoriously impermeable Anglo-American markets. According to an article in The Wall Street Journal about 'Fiction's Global Crime Wave', published at the height of the Stieg-Larsson craze: 'Detective novels from Japan, Nigeria, Germany and Korea are pouring into the U.S. as publishers hunt for the next "Girl With the Dragon Tattoo"' (Alter 2010).

Local crime writing in the European semi-periphery of the Nordic countries arose out of the generic forms originating, for the most part, in Anglo-American traditions. In the post-War period, Scandinavian crime writers absorbed and imitated the American hardboiled detective novel and the British clue-puzzle, notable examples being the Swedish queen of the 'whodunit', Maria Lang, the Dane Else Fischer and the Norwegian Gerd Nyquist (Wendelius 1999a: 46; Egholm Andersen 2010; Skei 2008: 79). Since the early 1970s, Scandinavian crime fiction has become more than adaptations in the periphery of Anglo-American predecessors. Crime fiction began to find its particular local expression in Scandinavia where the 'social work' of the crime 
genre became acted out, mediated and consumed on the stage of the Scandinavian welfare state. Since then, Scandinavian crime fiction has become a dramatic form that both adopt central concerns in crime writing while seeking to present content and forms specific to local social realities and traditions.

Curiously, in the first decade of the twenty-first century, this local Scandinavian variant became a new centre from where not only translated novels but also subtitled TV drama would spread to the rest of the world, notably with the success of original Danish TV series, Swedish and Anglo-American adaptations of novels by Henning Mankell (Wallander with Kenneth Brannagh as Inspector Wallander; Left Bank Pictures/Yellow Bird, 2008-2016) and Stieg Larsson (The Girl with the Dragon Tattoo; David Pincher 2011); TV series such as Forbrydelsen (The Killing ) and the Danish-Swedish co-production Broen/Bron (2011, 2013, 2015, The Bridge) were remade to serve other local contexts when, for instance, The Bridge was relocated from the Öresund Bridge between Sweden and Denmark to the tunnel connecting the UK and France in The Tunnel (2013) and the Bridge of the Americas between Mexico and the US in FX's The Bridge (2013-2014). The success of Nordic Noir TV drama in the UK has arguably influenced series such as the Welsh and bi-lingual $\underline{\mathrm{Y} \text { Gwyll/Hinterland }}$ (S4C/BBC One Wales, 2013/2014), and Nordic Noir has been taken up by UK-based crime writers such as Torquil MacLeod with his Malmö Mysteries and in Quentin Bates's Gunnhildur series, as well as in Simon Donald's TV-crime thriller Fortitude (Sky Atlantic, 2015) set in Arctic Norway. These recent examples demonstrate that Scandinavian crime fiction, while still mostly set in a Nordic country, preferably in cold, snowy landscapes, does not necessarily need to be written in a Scandinavian language by Scandinavians.

As such, Scandinavian crime fiction can be viewed as a new kind of centre in the global 
network of crime fiction and world literature. Itself an imitation of or a new accent to popular forms originating in the Anglo-American global centres, it has given rise to new accents at home and further afield. This new centre of popular fictions may only hold for a while, yet as a global commercial, cultural and literary phenomenon, thoroughly localized in national and regional settings but addressing widely shared concerns relevant to our fluid, fast-paced globalizing world, it is worthwhile, as I hope this book will demonstrate, to pause and consider what Scandinavian crime fiction, written and read over the past five decades, may tell us about our world, seen, as it always is, from a particular, recognizable yet foreign location. 